\title{
Lack of Molecular-Anatomical Evidence for GABAergic Influence on Axon Initial Segment of Cerebellar Purkinje Cells by the Pinceau Formation
}

\author{
Atsushi Iwakura, ${ }^{1}$ Motokazu Uchigashima, ${ }^{1}$ Taisuke Miyazaki, ${ }^{1}$ Miwako Yamasaki, ${ }^{1}$ and Masahiko Watanabe ${ }^{1,2}$ \\ ${ }^{1}$ Department of Anatomy, Hokkaido University Graduate School of Medicine, Sapporo 060-8638, Japan, and ${ }^{2 J a p a n}$ Science and Technology Agency, Core \\ Research for Evolutional Science and Technology, Sanbancho, Chiyoda-ku, Tokyo 102-0075, Japan
}

The axon initial segment (AIS) of cerebellar Purkinje cells (PCs) is embraced by ramified axons of GABAergic basket cells (BCs) called the pinceau formation. This unique structure has been assumed to be a device for the modulation of PC outputs through electrical and/or GABAergic inhibition. Electrical inhibition is supported by enriched potassium channels, absence of sodium channels, and developed septate-like junctions between $\mathrm{BC}$ axons. The neurochemical basis for GABAergic inhibition, however, has not been well investigated. Here we addressed this issue using C56BL/6 mice. First, we confirmed previous observations that typical synaptic contacts were rare and confined to proximal axonal portions, with the remaining portions being mostly covered by astrocytic processes. Then we examined the expression of molecules involved in GABAergic signaling, including GABA synthetic enzyme glutamic acid decarboxylase (GAD), vesicular GABA transporter vesicular inhibitory amino acid transporter (VIAAT), cytomatrix active zone protein bassoon, GABA receptor $\mathrm{GABA}_{\mathrm{A}} \mathrm{R} \alpha 1$, and cell adhesion molecule neuroligin-2. These molecules were recruited to form a functional assembly at perisomatic BC-PC synapses and along the AIS of hippocampal and neocortical pyramidal cells. GAD and VIAAT immunogold labeling was five times lower in the pinceau formation compared with perisomatic BC terminals and showed no accumulation toward the AIS. Moreover, bassoon, neuroligin-2, and $\mathrm{GABA}_{\mathrm{A}} \mathrm{R} \alpha 1$ formed no detectable clusters along the ankyrin-G-positive AIS proper. These findings indicate that GABAergic signaling machinery is organized loosely and even incompletely in the pinceau formation. Together, BCs do not appear to exert GABAergic synaptic inhibition on the AIS, although the mode of action of the pinceau formation remains to be explored.

\section{Introduction}

The axon initial segment (AIS) and node of Ranvier are characterized by a unique membrane undercoating and molecular organization specialized for impulse conduction (Ogawa and Rasband, 2008; Debanne and Rama, 2011). In these domains, voltage-gated sodium channels $\left(\mathrm{Na}_{\mathrm{V}}\right)$ are densely accumulated to generate action potentials, and voltage-gated potassium channels $\left(\mathrm{K}_{\mathrm{V}}\right)$ are to modulate their amplitude, duration, and frequency (Clark et al., 2009). In addition, specific cell adhesion molecules, scaffolds, and cytoskeletons, such as L1-CAM, ankyrin-G (AnkG), and $\beta \mathrm{IV}$ spectrin, are recruited to organize functional molecular assembly (Kordeli et al., 1995; Berghs et al., 2000). The AIS in cortical pyramidal and granule cells is the target for neuronal excitability modulation by specific GABAergic interneurons, called the axo-axonic or chandelier cells (Somogyi, 1977). At axo-axonic synapses, presynaptic elements contain GABA, the GABA synthetic enzyme glutamic acid decarboxylase (GAD),

Received April 4, 2012; revised May 8, 2012; accepted May 11, 2012.

Author contributions: M.W. designed research; A.I. and M.U. performed research; T.M. and M.Y. contributed unpublished reagents/analytic tools; A.I. and M.U. analyzed data; M.Y. and M.W. wrote the paper.

This study was supported by Grants-in-Aid for Scientific Research 19100005 (M.W.), 24220007 (M.W.), and 23800001 (M.U.)

Correspondence should be addressed to Masahiko Watanabe, Department of Anatomy, Hokkaido University Graduate School of Medicine, Sapporo 060-8638, Japan. E-mail: watamasa@med.hokudai.ac.jp.

DOI:10.1523/JNEUROSCI.1651-12.2012

Copyright $\odot 2012$ the authors $\quad 0270-6474 / 12 / 329438-11 \$ 15.00 / 0$ and the plasmalemmal GABA transporter GAT-1 (Peters et al., 1982; Freund et al., 1983; Somogyi et al., 1985; DeFelipe and González-Albo, 1998). Moreover, postsynaptic membranes express $\mathrm{GABA}_{\mathrm{A}}$ receptors, particularly those containing the $\alpha 2$ subunit (Nusser et al., 1996). Thus, molecules required for GABAergic transmission are functionally organized in the AIS, which is thought to modulate the timing and frequency of action potential firing and contribute to synchronous oscillations in cortical regions (Howard et al., 2005).

Basket cells (BCs) strongly inhibit Purkinje cells (PCs) in the cerebellum. During early postnatal life, axon collaterals originating from three to seven BCs descend to form GABAergic perisomatic synapses and further embrace the AIS of PCs to construct the pinceau formation, a cone-shaped structure at the base of PC somata (Roman y Cajal, 1911; Gobel, 1971; Sotelo and Llinás, 1972; Palay and Chan-Palay, 1974; Rosina et al., 1999; Gianola et al., 2003; Ango et al., 2004; Sotelo, 2008; Ichikawa et al., 2011). The AIS of PCs is enriched with $\mathrm{Na}_{\mathrm{V}} 1.6, \mathrm{~L} 1-\mathrm{CAM}$ neurofascin, AnkG, and $\beta$ IV spectrin (Zhou et al., 1998; Jenkins and Bennett, 2001) and triggers action potentials (Foust et al., 2010). BC axons make direct contact with the AIS, but synaptic contacts are rare compared with the hippocampus and neocortex. Instead, the AIS is mostly covered with astrocytic processes in PCs (Palay, 1974; Somogyi and Hamori, 1976; Bobik et al., 2004; Sotelo, 2008).

Given the strategic location and similarity to the axon cap of teleost Mauthner cells, the pinceau formation has been assumed 
Table 1. Primary antibodies used in the present study

\begin{tabular}{|c|c|c|c|c|}
\hline Molecule & Sequence (NCBI \#) & Host & Specificity & Reference \\
\hline AnkG & 1708-1726 (NP_733924.2) & $\mathrm{Rb} / \mathrm{GP}$ & $\mathrm{IB} / \mathrm{PT}$ & Present study (Fig. 3) \\
\hline Bassoon & Rat bassoon & Ms-mAb & & Assay designs (VAM-PSO03) \\
\hline Car8 & $33-61$ (ВC010773) & $\mathrm{Rb} / \mathrm{GP} / \mathrm{G}_{0}$ & $\mathrm{IB} / \mathrm{PT}$ & Patrizi et al. (2008) \\
\hline $\mathrm{GABA}_{\mathrm{A}} \mathrm{R} \alpha 1$ & 369-386 (NM_010250) & $\mathrm{Rb} / \mathrm{GP}$ & IB/HEK & Ichikawa et al. (2011) \\
\hline GAD & $268-593(A 28072)$ & $\mathrm{Rb} / \mathrm{G}_{0}$ & $\mathrm{IB} / \mathrm{PT}$ & Yamada et al. (2001) \\
\hline GAT-1 & 1-46/564-599 (NM_178703) & $\mathrm{Rb} / \mathrm{GP}$ & IB/HEK & Present study (Fig. 2) \\
\hline GLAST & 503-553 (NM148938) & $\mathrm{Rb} / \mathrm{GP} / \mathrm{G}_{0}$ & $\mathrm{IB}$ & Shibata et al. (1997) \\
\hline GLT-1 & 540-572 (NM_001077514) & $\mathrm{Rb} / \mathrm{GP} / \mathrm{G}_{0}$ & $\mathrm{IB}$ & Yamada et al. (1998) \\
\hline $\mathrm{K}_{\mathrm{v}} 1.1$ & 478-492 (NM_010595) & $\mathrm{Rb} / \mathrm{GP}$ & IB/HEK/PT & Present study (Fig. 8) \\
\hline$K_{\mathrm{v}} 1.2$ & 482-496 (NM_008417) & $\mathrm{Rb} / \mathrm{GP}$ & IB/HEK/PT & Present study (Fig. 8) \\
\hline pan- $\mathrm{Na}_{\mathrm{v}}$ & 1490-1508 (NM_018733) & $\mathrm{Rb}$ & $\mathrm{IB} / \mathrm{PT}$ & Present study (Fig. 3) \\
\hline NL2 & 732-761 (NP_12455) & $\mathrm{Rb} / \mathrm{GP}$ & IB/HEK & Present study (Fig. 6) \\
\hline PV & 1-110 (NM_013645) & $\mathrm{Rb} / \mathrm{GP} / \mathrm{G}_{0}$ & $\mathrm{IB}$ & Nakamura et al. (2004) \\
\hline PSD-95 & $1-62$ (D50621) & $\mathrm{Rb} / \mathrm{GP}$ & $\mathrm{IB}$ & Fukaya and Watanabe (2000) \\
\hline VIAAT & $31-112$ (BC052020) & $\mathrm{Rb} / \mathrm{GP} / \mathrm{G}_{0}$ & & Miyazaki et al. (2003) \\
\hline
\end{tabular}

NCBI, National Center for Biotechnology Information; Ms-mAb, mouse monoclonal antibody; Go, goat polyclonal antibody; GP, guinea pig polyclonal antibody; HEK, immunoblot with transfected HEK cell lysates; IB, immunoblot with brain homogenates; $\mathrm{Rb}$, rabbit polyclonal antibody; $\mathrm{PT}$, preabsorption test.

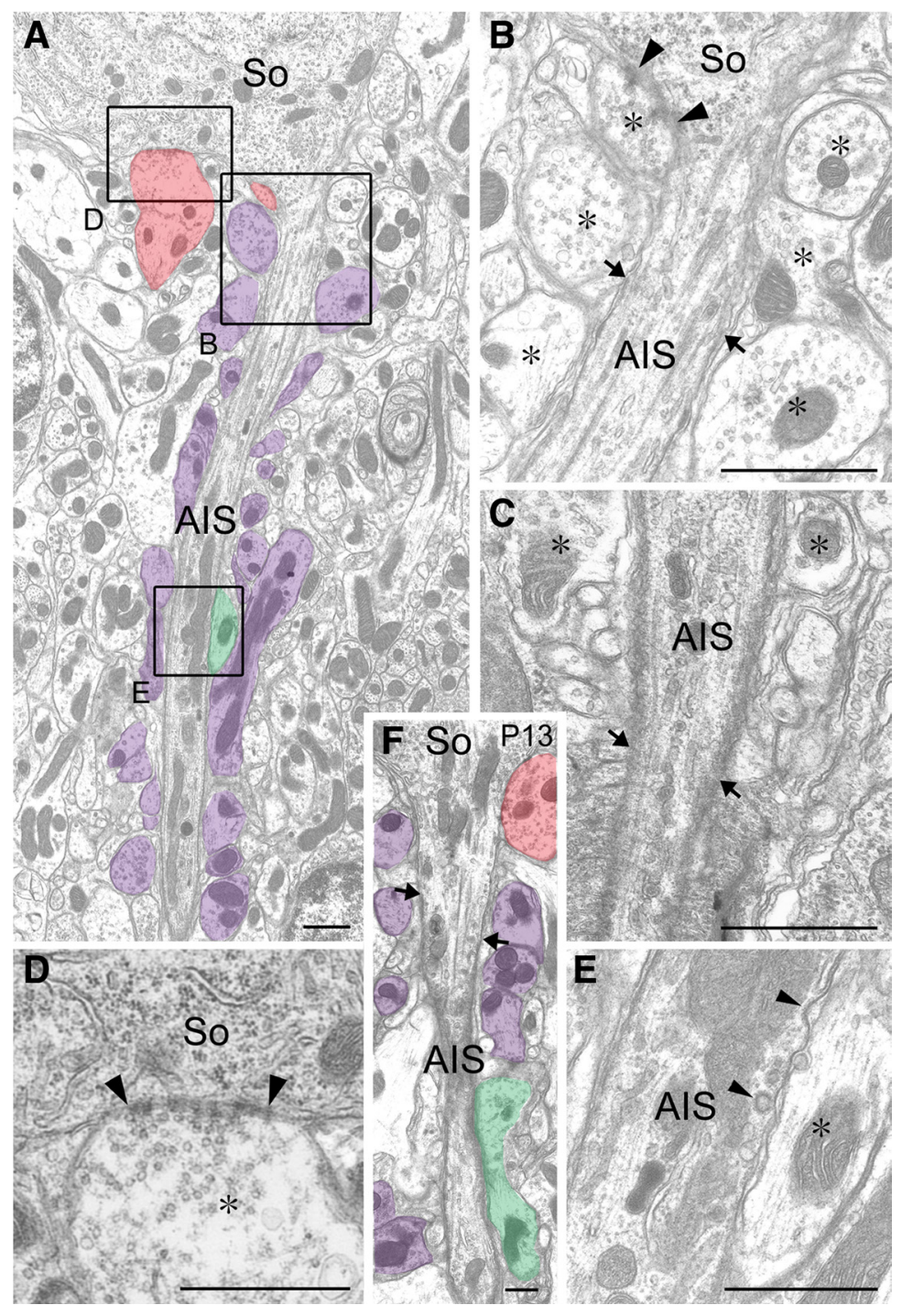

Figure 1. Electron micrographs showing the pinceau formation and AIS of PC in adult $(\boldsymbol{A}-\boldsymbol{E})$ and postnatal day $13(\boldsymbol{F})$ mice. $\boldsymbol{A}$, $\boldsymbol{F}$, Low-power images through the AIS. The AIS starts from the conical apex of PC somata (So). Profiles of BC axons forming symmetrical synapses are pseudocolored in red, those separated from the AIS with putative astroglial sheets in purple, and those directly contacting the AIS in green. $\boldsymbol{B}-\boldsymbol{E}$, Enlarged images of the beginning of a $\mathrm{PC}$ axon forming a symmetrical synaptic contact (arrowheads; $\boldsymbol{B}$ ), the end of the AIS surrounded by the first myelin sheath (arrows; $\boldsymbol{C}$ ), the axon hillock forming a symmetrical synaptic contact (arrowheads; $\boldsymbol{D}$ ), and the middle of the AIS directly contacted by a BC axon (E). Arrows in $\boldsymbol{B}$ and $\boldsymbol{F}$ indicate the starting point of the membrane undercoating. Asterisks in $\boldsymbol{B}-\boldsymbol{E}$ indicate $B C$ axon profiles. Scale bars, $250 \mathrm{~nm}$. to regulate PC firing through GABAergic inhibition and electrical inhibition by imposing a passive hyperpolarizing potential on the AIS (Korn and Axelrad, 1980; Gabbott et al., 1986). Distinct molecular-anatomical organizations in the pinceau formation, such as high $\mathrm{K}_{\mathrm{V}}$ expression, absence of $\mathrm{Na}_{\mathrm{V}}$, and developed septatelike junctions (Sotelo and Llinás, 1972; Wang et al., 1994; Laube et al., 1996; Bobik et al., 2004), are thought to support the hypothesized electrical inhibition. However, findings regarding GABAergic inhibition are still fragmented and inconclusive. In the present study, we compare the molecular architecture in the pinceau formation with that in perisomatic BC-PC synapses and cortical axo-axonic synapses. Here we report the lack of neurochemical evidence for GABAergic inhibition.

\section{Materials and Methods}

Animal and section preparation. C57BL/6 mice of either sex at 2 months of age (adult) and postnatal day 13 were used. Under deep anesthesia with pentobarbital $(100 \mathrm{mg} / \mathrm{kg}$ body weight, i.p.), mice were fixed transcardially with $4 \%$ paraformaldehyde in $0.1 \mathrm{M}$ phosphate buffer (PB), pH 7.2, for light microscopy, 2\% paraformaldehyde/2\% glutaraldehyde in $\mathrm{PB}$ for conventional electron microscopy, and $4 \%$ paraformaldehyde $/ 0.1 \%$ glutaraldehyde in $\mathrm{PB}$ for immunoelectron microscopy. Sections for light microscopy (50 $\mu \mathrm{m}$ in thickness) and postembedding immunogold $(400 \mu \mathrm{m})$ were prepared with a microslicer (VT1000S; Leica). For postembedding immunogold electron microscopy, sections were cryoprotected with $30 \%$ sucrose in $0.1 \mathrm{M} \mathrm{PB}$ and frozen rapidly with liquid propane in an EM CPC unit (Leica). Frozen sections were immersed in $0.5 \%$ uranyl acetate in methanol at $-45^{\circ} \mathrm{C}$ in an AFS freeze-substitution unit (Leica), infiltrated at $-45^{\circ} \mathrm{C}$ with Lowicryl HM-20 resin (Lowi), and polymerized with UV light. For conventional electron microscopy, cerebellar 
slices were postfixed in $2 \%$ osmium tetroxide for $1 \mathrm{~h}$, stained in block with $2 \%$ uranyl acetate for $20 \mathrm{~min}$, dehydrated, and embedded in Epon 812. Ultrathin sections were prepared with an ultramicrotome (UltraCut; Leica).

Antibodies. In the present study, we produced polyclonal antibodies against mouse AnkG, GAT-1, $\mathrm{K}_{\mathrm{V}} 1.1, \mathrm{~K}_{\mathrm{V}} 1.2, \mathrm{Na}_{\mathrm{V}} 1.1$, and neuroligin-2 (NL2), whose antigen sequences and host species are summarized in Table 1. Glutathione $S$-transferase fusion proteins were used for antigens of GAT-1 and NL2 antibodies by subcloning their cDNA fragments into the BamHI/EcoRI site of the pGEX4T-2 plasmid (GE Healthcare). Synthetic peptides coupled to keyhole limpet hemocyanin were used for antigens of AnkG, $\mathrm{K}_{\mathrm{V}} 1.1, \mathrm{~K}_{\mathrm{V}} 1.2$, and $\mathrm{Na}_{\mathrm{V}} 1.1$ antibodies. Because the sequence of amino acid residues 14901508 of $\mathrm{Na}_{\mathrm{V}} 1.1$ is common to all $\mathrm{Na}_{\mathrm{V}}$ subunits $\left(\mathrm{Na}_{\mathrm{V}} 1.1-\mathrm{Na}_{\mathrm{V}} 1.9\right)$, the produced antibody was termed pan- $\mathrm{Na}_{\mathrm{V}}$ antibody. Immunization and affinity purification were performed as reported previously (Watanabe et al., 1998). The specificity of the raised antibodies was tested by immunoblot with mouse brain homogenates, transfected human embryonic kidney (HEK293T) cells using pTracer-CMV2 mammalian expression vectors (Invitrogen), and preabsorption testing. We also used antibodies against bassoon, carbonic anhydrase-8 (Car8), $\mathrm{GABA}_{\mathrm{A}}$ receptor $\alpha 1$ subunit $\left(\mathrm{GABA}_{\mathrm{A}} \mathrm{R} \alpha 1\right), 65 / 67 \mathrm{kDa} \mathrm{GAD}$, plasmalemmal glutamate transporter GLT-1 and plasmalemmal glutamate-aspartate transporter GLAST, parvalbumin (PV), and vesicular inhibitory amino acid transporter (VIAAT), whose antigen sequences, host species, specificity, and references are summarized in Table 1.

Immunohistochemistry. All immunohistochemical incubations were performed using the free-floating method at room temperature. For immunofluorescence, microslicer sections were successively incubated with $10 \%$ normal donkey serum for $20 \mathrm{~min}$, followed by a mixture of primary antibodies overnight $(1 \mu \mathrm{g} / \mathrm{ml})$. The following day, sections were incubated, after washing, in a mixture of Alexa Fluor 488-labeled, indocarbocyanine (Cy3)-labeled, or indodicarbocyanine (Cy5)labeled species-specific secondary antibodies for $2 \mathrm{~h}$ at a dilution of 1:200 (Invitrogen; Jackson ImmunoResearch). PBS was used as dilution and washing buffers. When necessary, sections were subjected to antigen-exposing pretreatment with $1 \mathrm{mg} / \mathrm{ml}$ pepsin (Dako) in $0.2 \mathrm{~N} \mathrm{HCl}$ at $37^{\circ} \mathrm{C}$ for $0.5-2 \mathrm{~min}$ (Watanabe et al., 1998). Images were taken with a confocal laser-scanning microscope (FV1000; Olympus) equipped with helium-neon/argon laser and PlanApo $(10 \times / 0.40)$ and PlanApoN $(60 \times / 1.42$, oil-immersion) objective lens (Olympus). To avoid cross-talk between multiple fluorophores, Alexa Fluor 488, Cy3, and Cy5 fluorescent signals were acquired sequentially using the 488,543 , and $633 \mathrm{~nm}$ excitation laser lines. All images show single optical sections $(640 \times 640$ pixels; pixel size, $110 \mathrm{~nm})$.

For preembedding silver-enhanced immunogold electron microscopy, microslicer sections were incubated with primary antibodies (1 $\mu \mathrm{g} / \mathrm{ml}$ ) overnight and then with $1.4 \mathrm{~nm}$ gold particle-conjugated antiguinea pig IgG (Nanogold; Nanoprobes) for $6 \mathrm{~h}$. The sections were silverenhanced with the HQ silver kit (Nanoprobes), post-fixed for $30 \mathrm{~min}$ with $1 \%$ osmium tetroxide in $\mathrm{PB}$, block-stained overnight with $1 \%$ aqueous
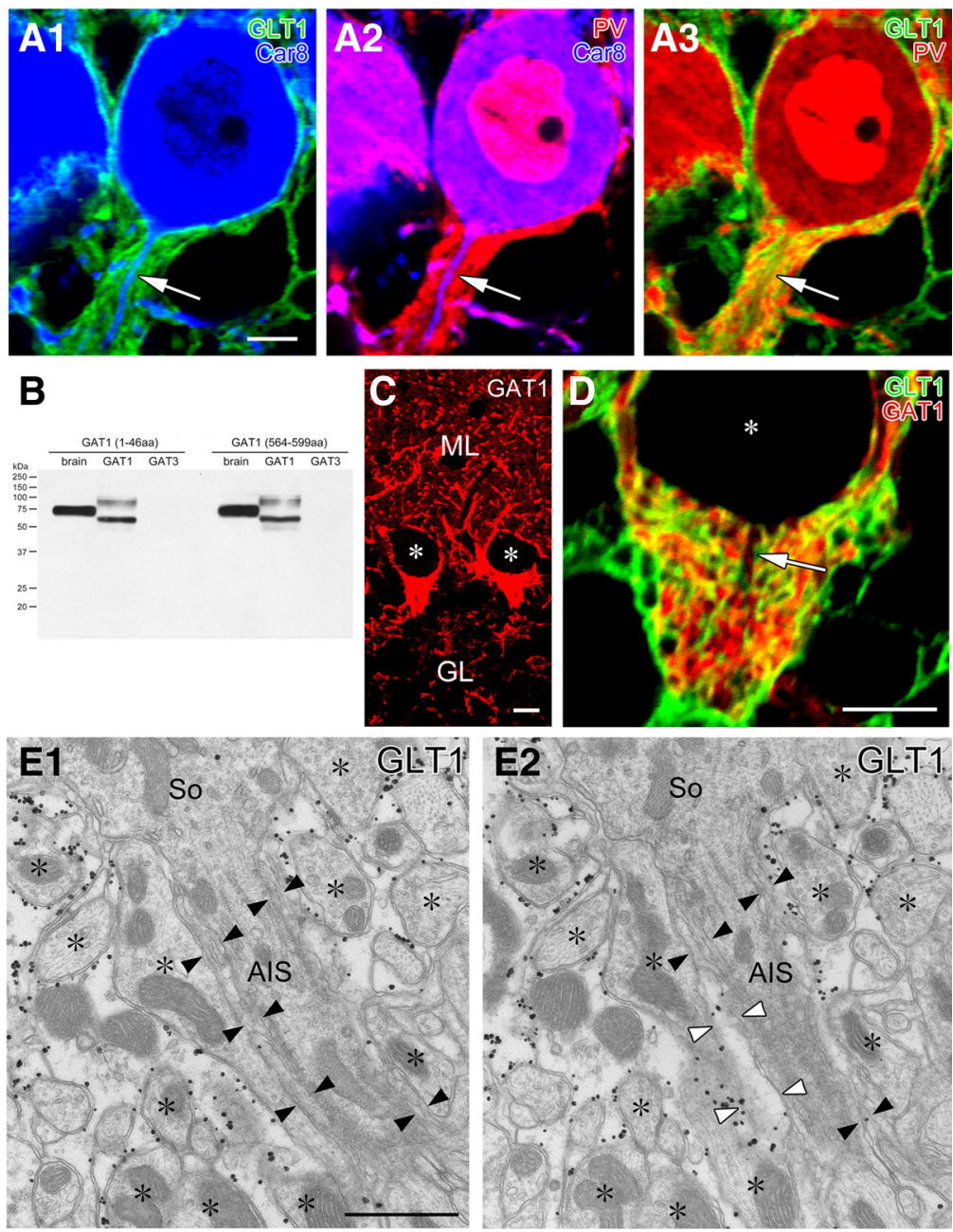

Figure 2. The AIS of PCs is mostly covered by astrocytic processes. $\boldsymbol{A}$, Triple immunofluorescence for GLT-1 (green; marker for astrocytes), Car8 (blue; PCs), and PV (red; PCs and BCs) is displayed in three combinations of fluorescent image pairs ( $\boldsymbol{A} 1$, GLT1 and the specificity of GABA transporter GAT-1 antibodies raised against two sequences (1-46 and 564-599 aa residues of mouse . Both antibodies recognize single protein bands at $75 \mathrm{kDa}$ in mouse brain homogenates (left lane) and HEK cell lysates (564-599) antibody (data not shown). D, Double immunofluorescence for GAT-1 (green) and GLT-1 (red) in the pinceau formamicroscopy for GLT-1 in the pinceau formation. The surface of the AIS is primarily covered by thin processes with low or negative GLT-1 labeling (filled arrowheads), which are continuous in adjacent sections to electron-lucent astrocytic processes with heavy GLT-1 labeling (open arrowheads). Scale bars: $\boldsymbol{A}, \boldsymbol{C}, \boldsymbol{D}, 5 \mu \mathrm{m} ; \boldsymbol{E}, 250 \mathrm{~nm}$.

uranyl acetate solution, dehydrated using graded alcohols, and embedded in Epon 812. In postembedding immunogold electron microscopy, ultrathin sections on nickel grids were etched with saturated sodiumethanolate solution for $1-5 \mathrm{~s}$ and treated successively with $2 \%$ normal goat serum for $20 \mathrm{~min}$, primary antibodies $(20 \mu \mathrm{g} / \mathrm{ml}$ for each) overnight, and $10 \mathrm{~nm}$ gold particles-conjugated anti-rabbit IgG (1:100; British Bio Cell International) for $2 \mathrm{~h}$. Tris-buffered saline (TBS), $\mathrm{pH} 7.4$, containing $0.03 \%$ Triton X-100 was used as dilution and washing buffers. After extensive washing, sections were fixed with $2 \%$ glutaraldehyde in TBS for $15 \mathrm{~min}$ and $1 \%$ osmium tetroxide for $20 \mathrm{~min}$, stained with $2 \%$ uranyl acetate for $10 \mathrm{~min}$, and Reynoid's lead citrate solution for $1 \mathrm{~min}$. Images were obtained using an H-7100 electron microscope (Hitachi).

Immunoblot. Mouse whole brains were homogenized using a Potter homogenizer with 15 strokes at $1000 \mathrm{rpm}$ in $10 \mathrm{vol}$ of ice-cold homogenizer buffer (0.32 м sucrose, 1 mm EDTA, 1 mm EGTA, 10 mm Tris-HCl, 

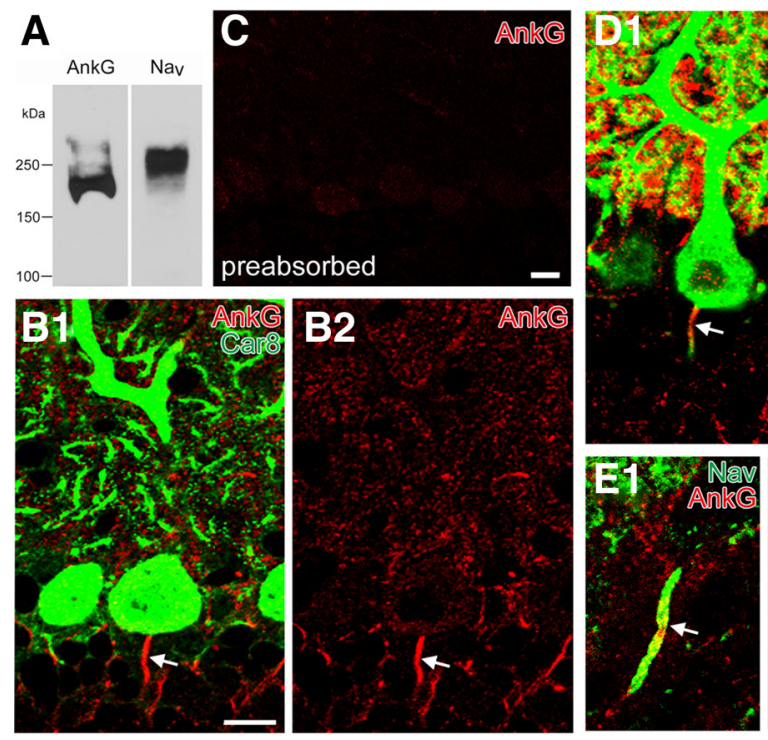

F
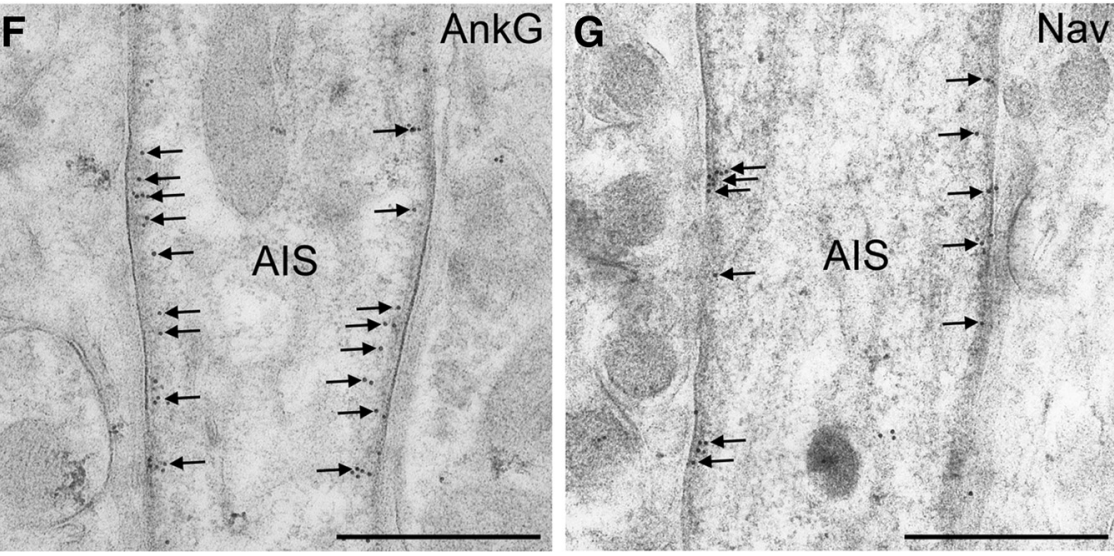

Figure 3. The specificity of $A n k G$ and pan- $\mathrm{Na}_{\mathrm{v}}$ antibody and their colocalization in the AIS. $\boldsymbol{A}$, Immunoblot with guinea pig AnkG antibody and rabbit pan-Na $\mathrm{Na}_{\mathrm{V}}$ antibody that recognize major bands at 200 or $250 \mathrm{kDa}$, respectively. $\boldsymbol{B}$, Double immunofluorescence for AnkG (red; B1, B2), Car8 (green; B1) in the cerebellar cortex. Arrow indicates a PC axon labeled for AnkG. C, Abolished immunofluorescent labeling in the cerebellar cortex with use of preabsorbed AnkG antibody. $\boldsymbol{D}$, Double immunofluorescence for

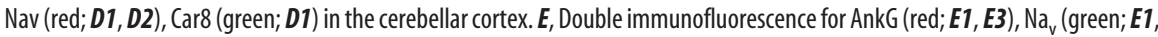
E2). Note colabeling in the AIS of PCS (arrow). F, G, Postembedding immunogold electron microscopy showing selective labeling

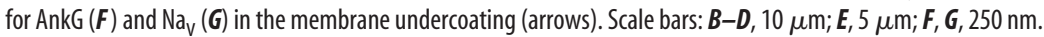

$\mathrm{pH}$ 7.2, and $0.4 \mathrm{~mm}$ phenylmethylsulfonyl fluoride). Nuclei and large debris were removed by centrifugation at $1000 \times g$ for $10 \mathrm{~min}$. The protein concentration was determined by the Lowry's method (Lowry et al., 1951). Homogenates were denatured with $50 \mathrm{~mm}( \pm)$-dithiothreitol at $65^{\circ} \mathrm{C}$ for $15 \mathrm{~min}$. Proteins $(20 \mu \mathrm{g} /$ lane) were separated by SDS-PAGE and electroblotted onto Immobilon-P Transfer Membrane (Millipore). After blocking with 5\% skimmed milk for $30 \mathrm{~min}$, membranes were incubated with primary antibodies $(1 \mu \mathrm{g} / \mathrm{ml})$ for $1 \mathrm{~h}$ and peroxidaseconjugated secondary antibodies for $1 \mathrm{~h}$ (1:10,000; Jackson ImmunoResearch). TBS containing $0.1 \%$ Tween 20 was used as dilution and washing buffers. Immunoreaction was visualized with an ECL chemiluminescence detection system (GE Healthcare).

\section{Results}

Infrequent synaptic contact at the AIS of PCs

We examined the AIS of mouse PCs by conventional electron microscopy (Fig. 1). Cylindrical axons descended through the pinceau formation from the conical apex at the base of PC somata, called the axon hillock (Fig. 1A). As reported previously (Palay et al., 1968; Palay and Chan-Palay, 1974; Peters et al., 1976; Somogyi and Hamori, 1976), the pinceau formation consisted of densely packed finger-like profiles of $\mathrm{BC}$ axons, abundant in mitochondria, whereas

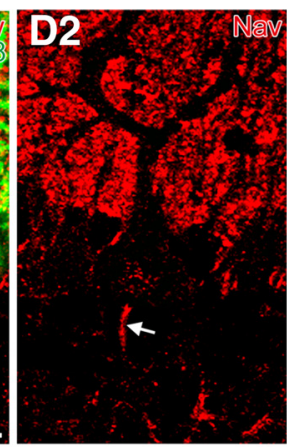

PC axons surrounded by the pinceau formation were characterized by the presence of fasciculated microtubules and an electron-dense undercoating of the axolemma. The undercoating started at a short distance from the beginning of PC axons (Fig. $1 B$, arrows).

$\mathrm{BC}$ axons frequently formed symmetrical contacts on PC somata, including the axon hillock (Fig. $1 A$, red profiles, $B, D$ ). These somatic contacts displayed typical synaptic specializations, i.e., vesicle accumulation in presynaptic terminals, parallel apposition of the presynaptic and postsynaptic membranes, and electrondense material associated with synaptic membranes and cleft (Fig. $1 B, D$ ). In the AIS, however, most of the $\mathrm{BC}$ axon profiles (Fig. $1 A$, purple profiles, $B, E$ ) were separated from the AIS with thin sheets of putative astrocytic processes. In 75 AIS profiles examined from two adult mice, we observed typical synaptic contact only at proximal axonal portions, in which the membrane undercoating had not started (Fig. 1 $A, B$ ). No typical synaptic specializations were seen at the site of direct BC-AIS contact in the remaining $\mathrm{PC}$ axons, although axolemmal ruffling and coated pits were often discerned at these sites (Fig. $1 A$, green profile, $E$, arrowheads). Measurement using electron micrographs revealed that $\mathrm{BC}$ axons covered only $9.2 \%$ of the total surface of the AIS (7.1 of $77.7 \mu \mathrm{m})$, and the remaining surface was covered by putative astrocytic processes (Fig. $1 B, E)$. A similar anatomical configuration was also observed in the AIS of PCs at postnatal day 13 (Fig. $1 F$ ), when the pinceau formation starts to be differentiated (Ango et al., 2004; Sotelo, 2008).

To cytochemically ascertain that the major covering elements were astrocytes, we performed triple immunofluorescence for GLT-1 (Fig. $2 \mathrm{~A}$, red), an astrocytic plasmalemmal glutamate transporter (Chaudhry et al., 1995), Car8 (Fig. $2 A, B$, green), a carbonic anyhydrase isoform selective to PCs (Jiao et al., 2005; Patrizi et al., 2008), and PV (Fig. 2A, blue), a calcium-binding protein expressed in PCs and BCs (Kosaka et al., 1993). In the pinceau formation, $B C$ axons were visualized as $\mathrm{PV}$-positive $\left(\mathrm{PV}^{+}\right) /$Car8-negative elements surrounding $\mathrm{PV}^{+} /$ Car $8^{+} \mathrm{PC}$ axons. Inside the pinceau formation, GLT- $1^{+}$astrocytic processes were elaborately interdigitated with $\mathrm{BC}$ axons. The intensive axoglial interdigitation was better appreciated using double immunofluorescence for GLT-1 and GAT-1 (Fig. 3B-D), a plasmalemmal GABA transporter enriched in BCs but not PCs (Itouji et al., 1996; Chiu et al., 2002). Nevertheless, exclusive astrocytic coverage of the AIS was not evident from immunofluorescence for GLT-1 (Fig. $2 A, D$ ) or GLAST, another astrocytic plasmalemmal glutamate transporter (data not shown).

We then used preembedding silver-enhanced immunogold electron microscopy for GLT-1 (Fig. 2E). Heavy labeling of metal particles was consistently observed on electron-lucent astrocytic 
processes enwrapping finger-like $\mathrm{BC}$ axon profiles (asterisks). In contrast, thin sheets enwrapping the AIS (filled arrowheads) were relatively high in electron density and were faint or negative in GLT-1 labeling. When investigated on serial sections, the thin sheets were found to be continuous with electron-lucent astrocytic processes expressing GLT-1 (open arrowheads), suggesting molecular/structural specialization of astrocytic processes enwrapping the AIS. Thus, consistent with the previous studies (Somogyi and Hamori, 1976; Sotelo, 2008), the surface of the AIS in PCs is mainly covered by astrocytes. This, together with infrequent synaptic contacts, suggests that the AIS of PCs is an unlikely target for GABAergic innervation.

\section{Limited molecular machinery for GABA synthesis and release in $\mathrm{BC}$ axons surrounding AIS}

We examined the expression of molecules involved in GABAergic signaling in the pinceau formation to obtain the neurochemical basis of its function. To this end, we produced an antibody to AnkG, a scaffolding protein in the AIS and the node of Ranvier (Kordeli et al., 1995), and used it as a marker of the AIS. The specificity of AnkG antibody was determined by immunoblot detection of a single major band at $200 \mathrm{kDa}$ (Fig. $3 A$ ), intense immunohistochemical labeling of putative AISs (Fig. 3B), the lack of immunohistochemical labeling when preabsorbed antibody was used (Fig. 3C), and overlapping distribution with $\mathrm{Na}_{\mathrm{V}}$ at putative AISs (Fig. $3 D, E$ ). Indeed, postembedding immunogold electron microscopy demonstrated selective labeling in the membrane undercoating of the AIS for both AnkG and $\mathrm{Na}_{\mathrm{V}}$ (Fig. $3 F, G)$.

We compared the expression of three presynaptic molecules: the GABA synthetic enzyme GAD (Kaufman et al., 1986), the vesicular GABA transporter VIAAT (McIntire et al., 1997), and cytomatrix active zone protein bassoon (tom Dieck et al., 1998), in the soma and AIS of PCs. By triple immunofluorescence, oval labeling for GAD and VIAAT was intense on the surface of Car8 ${ }^{+}$ PC somata (Fig, $4 A, B$, red, arrowhead), as reported previously (Oertel et al., 1981; Chaudhry et al., 1998). Clearly, GAD and VIAAT immunoreactivities were weak and diffuse in the pinceau formation, in which no particular accumulation or gradient toward $\mathrm{AnkG}^{+}$AISs was apparent (Fig. 4A, B, arrows). As for bassoon, flat puncta were observed on PC somata, whereas no such punctate labeling was found in the pinceau formation or along the AIS ( $n=41$ AISs; Fig. $4 C$ ).

Preembedding silver-enhanced immunogold electron microscopy revealed that GAD (Fig. $5 A, B$ ) and VIAAT (data not shown) were concentrated in vesicle-accumulating portions of perisomatic BC terminals (Fig. 5A), whereas they were sparse in $\mathrm{BC}$ axons around the AIS (Fig. $5 B$ ). The density of GAD and VIAAT labeling was measured by postembedding immunogold electron microscopy (Fig. 5C-F). The mean number of gold particles per $1 \mu \mathrm{m}^{2}$ of $\mathrm{BC}$ axon profiles was five times higher in perisomatic profiles than in the pinceau formation: 169 and 34 particles $/ \mu \mathrm{m}^{2}$, respectively, for GAD (the total measured area, 5.60 and $8.94 \mu \mathrm{m}^{2}$ ), and 185 and 39 particles/ $\mu \mathrm{m}^{2}$, respectively, for VIAAT
(8.65 and $11.9 \mu \mathrm{m}^{2}$ ). Postembedding immunogold labeling for bassoon was observed near the presynaptic membrane at perisomatic $\mathrm{BC}$ synapses, whereas labeling was absent around the region of BC-AIS contact (Fig. 5G,H). The labeling density per $1 \mu \mathrm{m}^{2}$ of $\mathrm{BC}$ axon profiles was 4.12 and 0 in perisomatic and peri-AIS BC axons (the total measured area, 4.11 and $6.51 \mu \mathrm{m}^{2}$ ), respectively. Synaptic specialization was consistently observed at perisomatic $\mathrm{BC}$ contact in immunoelectron microscopic images (Fig. $5 A, C, E, G$, filled arrowheads) but not at BC-AIS contact points (Fig. $5 B, D, F, H$, open arrowheads). Therefore, compared with perisomatic BC synapses, the molecular machinery for GABA synthesis and release is organized loosely and incompletely at BC-AIS contacts.

\section{Lack of $\mathrm{GABA}_{\mathrm{A}} \mathrm{R} \alpha 1$ and NL2 expression along the AnkG ${ }^{+}$ AIS portion}

We then investigated the expression of two postsynaptic molecules at GABAergic synapses, i.e., $\mathrm{GABA}_{\mathrm{A}} \mathrm{R} \alpha 1$, a major $\mathrm{GABA}_{\mathrm{A}}$ receptor subunit in PCs (Fritschy and Panzanelli, 2006), and NL2, a cell adhesion molecule at GABAergic synapses (Varoqueaux et al., 2004). The specificity of NL2 antibody was shown by immunoblot detection of a single major band at $100 \mathrm{kDa}$ in both mouse brain homogenates and HEK cell lysates transfected with NL2 cDNA (Fig. 6B). Specificity was further seen with close apposition to $\mathrm{GAD}^{+}$puncta on somata, dendrites, and synaptic glomeruli (Fig. 6C) and the lack of immunohistochemical staining with preabsorbed NL2 antibody (data not shown).

$\mathrm{GABA}_{\mathrm{A}} \mathrm{R} \alpha 1$ and NL2 were clustered on the surface of Car8 ${ }^{+}$ PC somata (Fig. 6A,D, single arrowheads), as reported previously (Richter et al., 1999; Fritschy and Panzanelli, 2006; Patrizi et al., 2008). However, no such clusters were found along AnkG ${ }^{+}$ portions of the AIS (Fig. 4A,D, arrows; 58 and 43 AISs analyzed for $\mathrm{GABA}_{\mathrm{A}} \mathrm{R} \alpha 1$ and NL2, respectively). Occasionally, clusters of $\mathrm{GABA}_{\mathrm{A}} \mathrm{R} \alpha 1$ and NL2 were found at the beginning or very proximal portions of PC axons. These portions were located at areas lacking AnkG (Fig. 4A, double arrowheads). The post- 


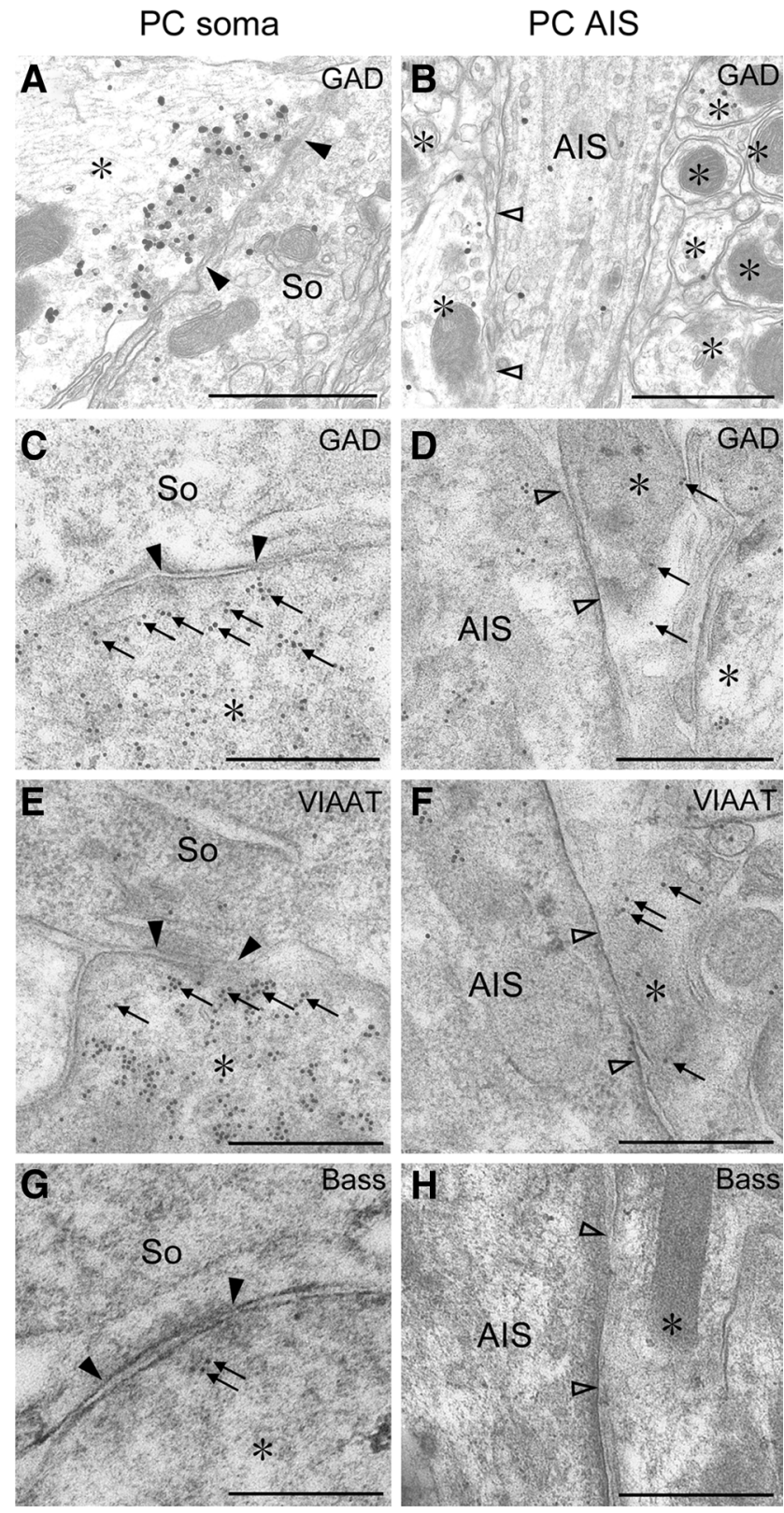

Figure 5. Preembedding $(\boldsymbol{A}, \boldsymbol{B})$ and postembedding $(\boldsymbol{C}-\boldsymbol{H})$ immunogold electron microscopy showing loose and incomplete assembly of presynaptic molecules for GABAergic synaptic transmission around the AIS of PCS. A-D, GAD.E, $\boldsymbol{F}$, VIAAT. $G, \boldsymbol{H}$, Bassoon (Bass). BC synapses on $P C$ somata (So) are shown in $A, C, E$, and $\boldsymbol{G}$ (filled arrowheads), whereas $B C$ axons contacting the AIS of $\mathrm{PC}$ are in $\boldsymbol{B}, \boldsymbol{D}, \boldsymbol{F}$, and $\boldsymbol{H}$ (open arrowheads). Asterisks indicate $B C$ axons and terminals. Scale bars, $250 \mathrm{~nm}$.

synaptic membrane was labeled for $\mathrm{GABA}_{\mathrm{A}} \mathrm{R} \alpha 1$ and NL2 at perisomatic BC synapses (Fig. $7 A, C$, filled arrowheads) using postembedding immunogold electron microscopy. The mean number per $1 \mu \mathrm{m}$ of the postsynaptic membrane was 7.93 (the total measured length, $8.64 \mu \mathrm{m}$ ). However, no immunogold particles were found at BC-AIS contacts (Fig. 7B, open arrowheads; the total measured length, $2.49 \mu \mathrm{m}$ ). The density of NL2 labeling was 3.50 and 0 at perisomatic BC synapses and BC-AIS contacts (the total measured length, 5.14 and 1.64 $\mu \mathrm{m})$, respectively. Therefore, in contrast to perisomatic BC synapses, $\mathrm{GABA}_{\mathrm{A}} \mathrm{R} \alpha 1$ and NL2 are not clustered along the spike-generating portion of AIS.

\section{Distinct molecular organization at AIS of hippocampal pyramidal cells}

In cortical regions of the telencephalon, axo-axonic or chandelier cells selectively and densely target the AIS of pyramidal cells (Somogyi, 1977; Somogyi et al., 1982). For comparison, the configuration of the five molecules was examined in the hippocampal CA3 region (Fig. $8 A-E$ ) and somatosensory cortex (Fig. $8 F-J$ ) by triple immunofluorescence for AnkG (green), GAD (blue), and one of VIAAT, bassoon, NL2, or GABA $\mathrm{A} \alpha 1$ (red). AnkG ${ }^{+}$AISs originated from the base of pyramidal cell somata (Fig. $8 A, F$, arrows). Many $\mathrm{GAD}^{+}$boutons were aligned along $\mathrm{AnkG}^{+} \mathrm{AISs}$ (Fig. $8 B-E, G-J$, arrows), as is the case at the somatic surface (arrowheads). Furthermore, $\mathrm{GAD}^{+}$boutons in the AIS were overlapped almost completely with VIAAT (Fig. $8 B, G$, arrows) and associated with bassoon (Fig. 8C,H, arrows), NL2 (Fig. 8D, I, arrows), and $\mathrm{GABA}_{\mathrm{A}} \mathrm{R} \alpha 1$ (Fig. $8 E$,J, arrows) clusters. Therefore, unlike PCs, a set of GABAergic molecules is recruited to axoaxonic contacts on the AIS of cortical pyramidal cells.

$\mathrm{BC}$ axons in the pinceau formation are known to highly express Shaker-type potassium channels $\mathrm{K}_{\mathrm{V}} 1.1$ and $\mathrm{K}_{\mathrm{V}} 1.2$ and their scaffolding protein postsynaptic density-95 (PSD-95) (Kistner et al., 1993; Wang et al., 1994; Laube et al., 1996; Fukaya and Watanabe, 2000). Using specific antibodies (Fig. 9A; Table 1), we confirmed intense labeling for $\mathrm{K}_{\mathrm{V}} 1.1, \mathrm{~K}_{\mathrm{V}} 1.2$, and PSD-95 in the pinceau formation, whereas they appeared very low or negative in the AIS of PCs (Fig. $9 B-D$ ). In contrast, $\mathrm{K}_{\mathrm{V}} 1.1$ and $\mathrm{K}_{\mathrm{V}} 1.2$ were expressed on the AIS but not in terminals of axo-axonic cells in hippocampal CA3 pyramidal cells (Fig. 9 E, F). PSD-95 was below the threshold of immunofluorescence detection in both the AIS and terminals (Fig. 9G). Thus, the organization of GABAergic signaling molecules and Shaker-type potassium channels at axoaxonic contacts in PCs are quite distinct from those in cortical pyramidal cells.

\section{Discussion}

The present study examined the molecular architecture required for GABAergic signaling in the pinceau formation. Our neurochemical data argue against a role for GABAergic inhibition within this structure.

Palay et al. (1968) found only one synapsing BC terminal from some 60 AIS profiles of rat PCs. Through three-dimensional reconstruction of 17 AISs with electron microscopic serial sections, Somogyi and Hamori (1976) counted 2.9 and 3.5 axo-axonic synapses per AIS in the rat and cat, respectively. Most of these synapses were located in the proximal one-third of the AIS. They further revealed that glial elements cover as much as 85.6 and $74.2 \%$ of the total AIS surface in the rat and cat, respectively. In the pinceau formation, septate-like junctions develop at contacts between finger-like processes of $\mathrm{BC}$ axons and also between $\mathrm{BC}$ axons and AISs. Interestingly, the vicinity of the latter contact lacks synaptic specialization, such as vesicle accumulation and membrane densities (Gobel, 1971; Sotelo and Llinás, 1972). In the present study, we examined 75 AIS profiles in mouse PCs and found $90.8 \%$ coverage by astrocytic elements. Although typical synaptic contacts were found at the very proximal portion of PC axons, we failed to find typical synaptic specializations in the remaining portions of the AIS. This may attributable to species difference or the lack of complete serial reconstruction of single AISs. Nevertheless, the rarity of axo-axonic synaptic contacts in PCs is common to all these studies and contrasts with frequent formation in the neocortex, hippocampus, and amygdala (for review, see Howard et al., 2005; Fig. 8). In these telencephalic regions, axo-axonic cells form terminal cartridges consisting of 
2-12 boutons along individual AISs. Single axo-axonic cells innervate as many as 250 (in the cortex) to 1200 (in the hippocampus) pyramidal cells (Somogyi et al., 1982; Li et al., 1992).

The above electron microscopic studies have clearly illustrated the unique structural features of the pinceau formation and the AIS of PCs. To clarify whether, and how, the molecular machinery for GABAergic transmission is organized in the pinceau formation, we investigated immunohistochemical localization of GAD, VIAAT, bassoon, NL2, and $\mathrm{GABA}_{\mathrm{A}} \mathrm{R} \alpha 1$, because all are highly accumulated at GABAergic synapses on somatodendritic elements in PCs (Oertel et al., 1981; Fritschy and Mohler, 1995; Chaudhry et al., 1998; Richter et al., 1999; Varoqueaux et al., 2004). Our examination confirmed that these molecules were clustered at perisomatic sites of PCs, thus ensuring the specificity and sensitivity of the present immunohistochemistry. Moreover, all these molecules were clearly and numerously detected along the AIS of pyramidal cells in the hippocampus and somatosensory cortex (Fig. 8). The functional organization of GABAergic molecules is consistent with previous studies demonstrating the localization of GABA and GAT-1 in presynaptic terminals of cortical and hippocampal axo-axonic cells (Peters et al., 1982; Somogyi et al., 1985; DeFelipe and GonzálezAlbo, 1998). The localization of $\mathrm{GABA}_{\mathrm{A}} \mathrm{R} \alpha 1$ and $\mathrm{GABA}_{\mathrm{A}} \mathrm{R} \alpha 2$ in the AIS of hippocampal pyramidal cells (Nusser et al., 1996) also support the functional organization seen in our study. GAD and VIAAT were detected in the pinceau formation, but their density of immunogold labeling was five times lower compared with perisomatic BC terminals. In addition, no particular accumulation toward the AIS was observed for these presynaptic molecules. Most importantly, no visible clusters were found for bassoon, NL2, and $\mathrm{GABA}_{\mathrm{A}} \mathrm{R} \alpha 1$ in the $\mathrm{AnkG}^{+}$AIS portion. Of these, $\mathrm{GABA}_{\mathrm{A}} \mathrm{R} \alpha 1$ is the sole $\alpha$ subunit expressed in PCs and essential for functional $\mathrm{GABA}_{\mathrm{A}}$ Rs in PCs, because spontaneous and evoked IPSCs are completely lost in PCs of $\mathrm{GABA}_{\mathrm{A}} \mathrm{R} \alpha 1$ knock-out mice (Fritschy and Mohler, 1995; Kralic et al., 2005; Fritschy et al., 2006; Fritschy and Panzanelli, 2006). All these findings indicate that, although GABA may be synthesized and transported into vesicles to some extent, molecular machinery for GABA release and sensing are not tightly organized into apposing presynaptic and postsynaptic elements within the pinceau formation. However, in hippocampal pyramidal cells, the majority of $\mathrm{GABA}_{\mathrm{A}} \mathrm{R} \alpha 1$-containing receptors are distributed on the extrasynaptic membrane at a much lower density than their synaptic counterparts (Kasugai et al., 2010). In this regard, we cannot exclude the possibility that $\mathrm{GABA}_{\mathrm{A}} \mathrm{R} \alpha 1$-containing receptors are distributed on the AIS of PCs at a subthreshold level by conventional immunofluorescence and postembedding immunoelectron microscopy. Thus, it is safe to conclude that, different from axo-axonic synapses in cortical pyramidal cells, the pinceau formation is unlikely to be the site or device for GABA-mediated synaptic inhibition.
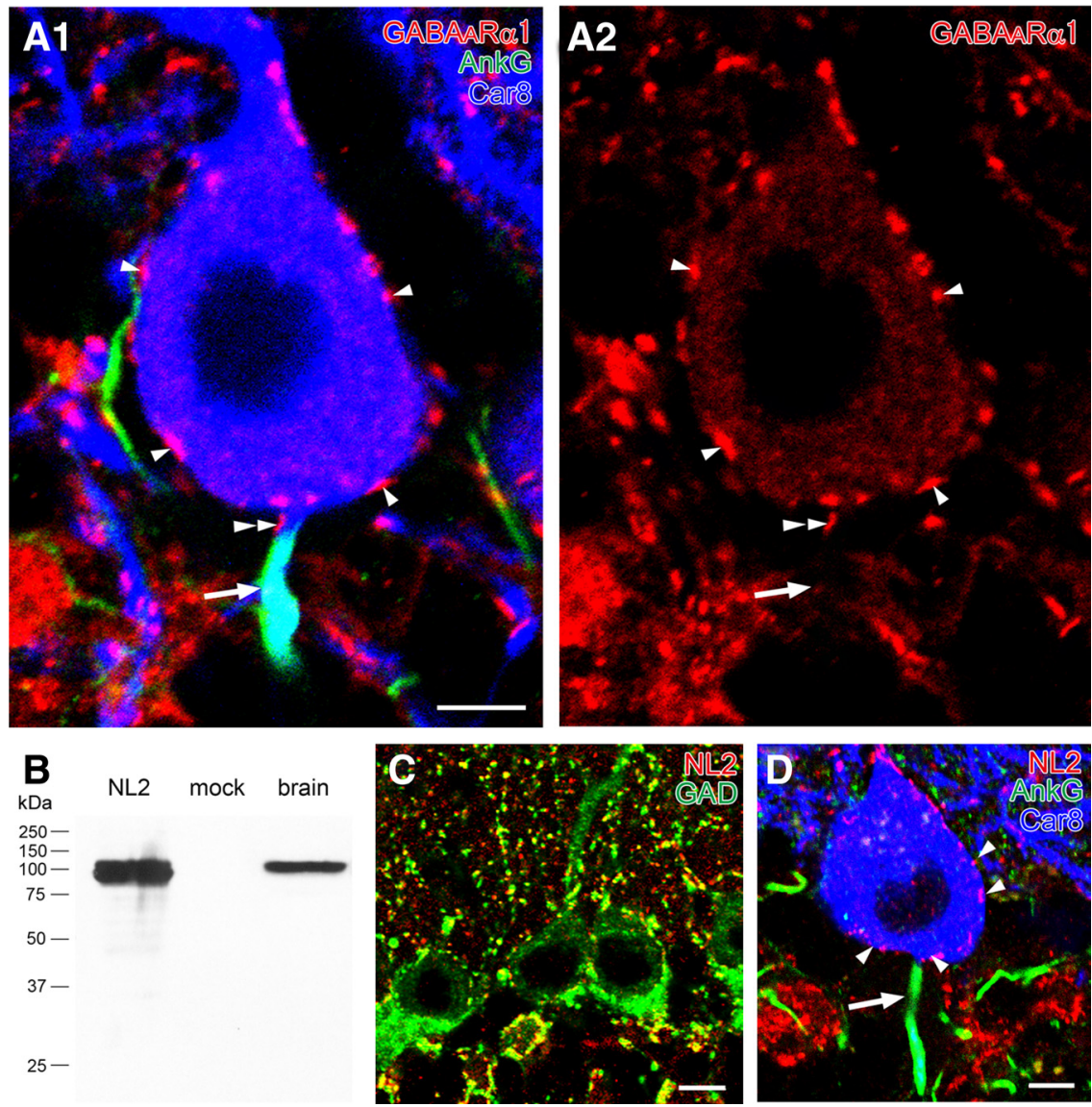

Figure 6. Immunofluorescence showing the lack of postsynaptic molecules required for GABAergic synapses on the AIS of PCs. $A$, Triple immunofluorescence for AnkG (green; A1), Car8 (blue; A1), and GABA $A_{A} R 1$ (red; A1, A2) in PCs. Note that GABA $A_{A}$ R 1-immunoreactive (right lane) but not in nontransfected HEK cell lysates (mock, middle lane). C, Double immunofluorescence for NL2 (red) and (arrowheads) but not on AnkG-labeled AISs (arrow). Scale bars: $5 \mu \mathrm{m} ; C, D, 10 \mu \mathrm{m}$.

GAT-1 is highly expressed in BC axons (Morara et al., 1996; Fig. $2 C, D)$. Synaptic action of GABA released by $\mathrm{Ca}^{2+}$ - dependent vesicular release is terminated by GAT-mediated uptake into neighboring neurons and glial cells. GAT also mediates $\mathrm{Ca}^{2+}$-independent nonvesicular release of GABA via reverse transport (Attwell et al., 1993). Because GAT cotransports $\mathrm{GABA}, 2 \mathrm{Na}^{+}$, and $\mathrm{Cl}^{-}$, reverse transport preferably occurs if the membrane potential is made positive enough or if $\left[\mathrm{Na}^{+}\right]_{\mathrm{i}}$ rises to a high enough level. Accordingly, it has been postulated that GAT contributes to spatiotemporal restriction of GABAergic inhibition by decreasing [GABA $]_{\mathrm{o}}$ in the physiological state and also strengthening of GABAergic inhibition by increasing $[\mathrm{GABA}]_{\mathrm{o}}$ on excessive activities of excitatory synapses. This molecular function will be important as a homeostatic and protective mechanism at conventional GABAergic synapses. However, it is difficult to apply this notion to the pinceau formation, because GABAergic molecular machinery is loosely and incompletely organized and also because the pinceau formation lacks $\mathrm{Na}_{\mathrm{V}}$ (Laube et al., 1996) (Fig. 4D,E). Thus, it seems unlikely that GAT-1 enriched in the pinceau formation mediates GABA release via reversed operation of this transporter.

It has been proposed that the pinceau formation regulates the excitability of PCs by electrical inhibition (Korn and Axelrad, 


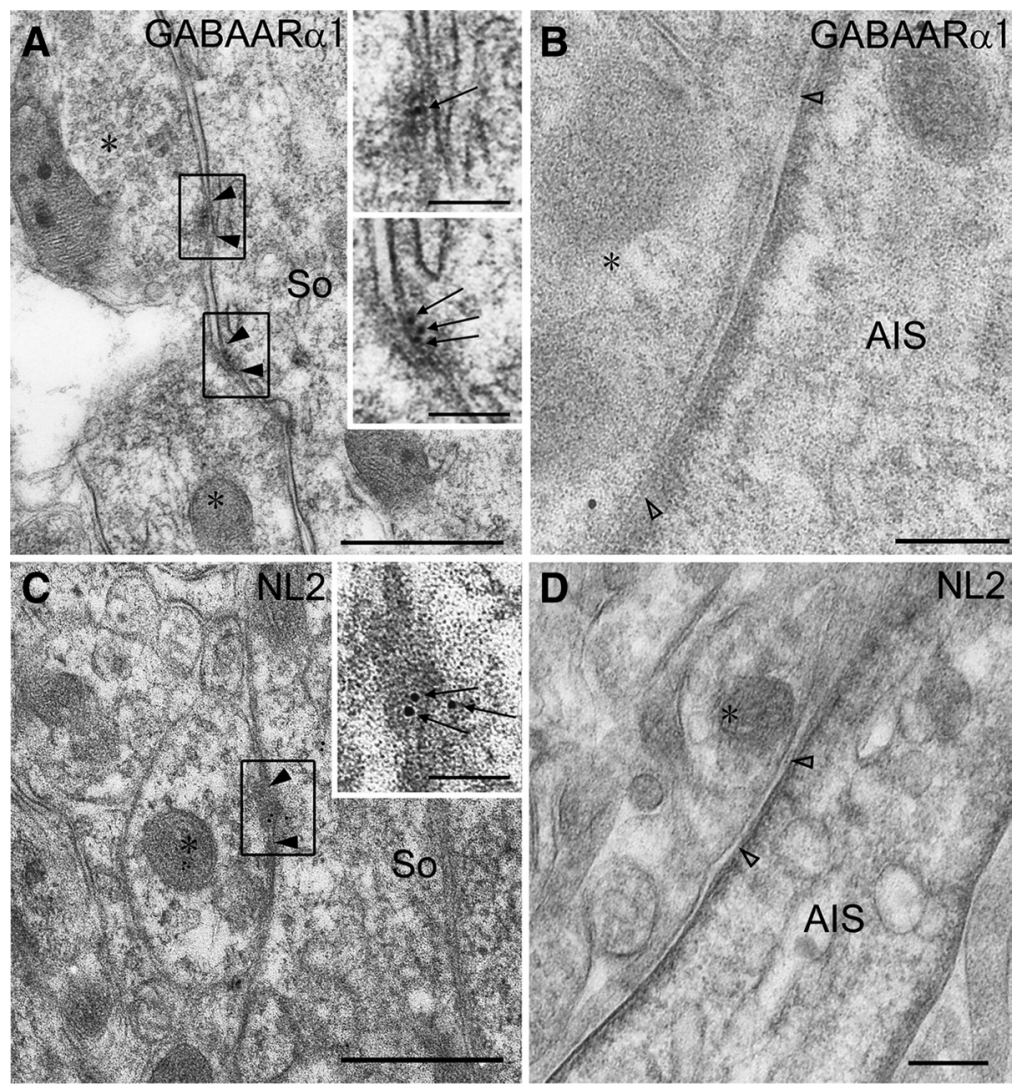

Figure 7. Postembedding immunogold electron microscopy showing no accumulation of postsynaptic molecules required for GABAergic synapses on the AIS of PCS. $A, B, G A B A_{A} R \alpha 1$. C, D, NL2. Immunogold particles for $G A B A_{A} R \alpha 1$ and NL2 are localized in the postsynaptic membrane of symmetrical synapses on $P C$ soma ( $S_{0} ; A, C$, filled arrowheads) but not on the AIS contacting $B C$ axons $(\boldsymbol{B}, \boldsymbol{D}$, open arrowheads). Asterisks indicate profiles of $B C$ axons. Scale bars, $250 \mathrm{~nm}$.

1980). This hypothesis is based on the structural similarity of the pinceau formation to the axon cap of the teleost Mauthner cell (Sotelo and Llinás, 1972; Nakajima and Kohno, 1978; Triller and Korn, 1980) and also the fact that the AIS of the Mauthner cell is hyperpolarized by an inward current originating from adjacent fibers ( $\mathrm{Fu}-$ rukawa and Furshpan, 1963). The failure in active impulse conduction in those terminals enables them to serve as passive current sources, with extracellular high resistivity allowing the current to channel mainly into the AIS of the Mauthner cell (Furukawa and Furshpan, 1963; Weiss and Faber, 2010). In this regard, the lack of $\mathrm{Na}_{\mathrm{V}}$ (Laube et al., 1996; Fig. 4D,E) and predominant localization of Shaker-type $\left(\mathrm{K}_{\mathrm{V}} 1.1\right.$ and $\left.\mathrm{K}_{\mathrm{V}} 1.2\right)$ potassium channels together with their scaffolding protein PSD-95 (Laube et al., 1996; Bobik et al., 2004; Fig. 9) may prevent active impulse conduction in the pinceau formation. Similarly, septatelike junctions developed in the pinceau formation, which have been postulated to form high resistance elements (Sotelo and Llinás, 1972; Faber and Korn, 1989), may allow currents to preferentially channel into the AIS of PCs and lead to hyperpolarization. In contrast, terminals of cortical axo-axonic cells lack the expression of $\mathrm{K}_{\mathrm{V}} 1.1, \mathrm{~K}_{\mathrm{V}} 1.2$, and PSD-95. Instead, $\mathrm{K}_{\mathrm{V}} 1.1$ and $\mathrm{K}_{\mathrm{V}} 1.2$ are expressed in the AIS of cortical pyramidal cells (Fig. 9). Thus, the unique molecular-structural configuration in the pinceau formation can be taken to support the electrical inhibition hypothesis, although its experimental proof and functional role remain elusive.

Together, it is thus possible that BCs exert two modes of inhibition at two distinct PC domains; GABAergic inhibition on PC somata by dense perisomatic synapses, and electrical inhibition on the AIS via the pinceau formation. In this regard, referring to the pinceau formation as "pinceau synapses" (Ango et al., 2004 ) is inappropriate and will mislead our understanding on this specialized cerebellar structure.

\section{References}

Ango F, di Cristo G, Higashiyama H, Bennett V, Wu P, Huang ZJ (2004) Ankyrin-based subcellular gradient of neurofascin, an immunoglobulin family protein, directs GABAergic innervation at Purkinje axon initial segment. Cell 119:257-272.

Attwell D, Barbour B, Szatkowski M (1993) Nonvesicular release of neurotransmitter. Neuron 11:401-407.

Berghs S, Aggujaro D, Dirkx R Jr, Maksimova E, Stabach P, Hermel JM, Zhang JP, Philbrick W, Slepnev V, Ort T, Solimena M (2000) betaIV spectrin, a new spectrin localized at axon initial segments and nodes of Ranvier in the central and peripheral nervous system. J Cell Biol 151:985-1002.

Bobik M, Ellisman MH, Rudy B, Martone ME (2004) Potassium channel subunit Kv3.2 and the water channel aquaporin-4 are selectively localized to cerebellar pinceau. Brain Res 1026:168-178.

Chaudhry FA, Lehre KP, van Lookeren Campagne M, Ottersen OP, Danbolt NC, StormMathisen J (1995) Glutamate transporters in glial plasma membranes: highly differentiated localizations revealed by quantitative ultrastructural immunocytochemistry. Neuron 15:711-720.

Chaudhry FA, Reimer RJ, Bellocchio EE, Danbolt NC, Osen KK, Edwards RH, Storm-Mathisen J (1998) The vesicular GABA transporter, VGAT, localizes to synaptic vesicles in sets of glycinergic as well as GABAergic neurons. J Neurosci 18:9733-9750.

Chiu CS, Jensen K, Sokolova I, Wang D, Li M, Deshpande P, Davidson N, Mody I, Quick MW, Quake SR, Lester HA (2002) Number, density, and surface/cytoplasmic distribution of GABA transporters at presynaptic structures of knock-in mice carrying GABA transporter subtype 1-green fluorescent protein fusions. J Neurosci 22:10251-10266.

Clark BD, Goldberg EM, Rudy B (2009) Electrogenic tuning of the axon initial segment. Neuroscientist 15:651-668.

Debanne D, Rama S (2011) Astrocytes shape axonal signaling. Sci Signal 4:pe11.

DeFelipe J, González-Albo MC (1998) Chandelier cell axons are immunoreactive for GAT-1 in the human neocortex. Neuroreport 9:467-470.

Faber DS, Korn H (1989) Electrical field effects: their relevance in central neural networks. Physiol Rev 69:821-863.

Foust A, Popovic M, Zecevic D, McCormick DA (2010) Action potentials initiate in the axon initial segment and propagate through axon collaterals reliably in cerebellar Purkinje neurons. J Neurosci 30:6891-6902.

Freund TF, Martin KA, Smith AD, Somogyi P (1983) Glutamate decarboxylase-immunoreactive terminals of Golgi-impregnated axoaxonic cells and of presumed basket cells in synaptic contact with pyramidal neurons of the cat's visual cortex. J Comp Neurol 221:263-278.

Fritschy JM, Mohler H (1995) GABAA-receptor heterogeneity in the adult rat brain: differential regional and cellular distribution of seven major subunits. J Comp Neurol 359:154-194.

Fritschy JM, Panzanelli P (2006) Molecular and synaptic organization of GABAA receptors in the cerebellum: Effects of targeted subunit gene deletions. Cerebellum 5:275-285.

Fritschy JM, Panzanelli P, Kralic JE, Vogt KE, Sassoè-Pognetto M (2006) Differential dependence of axo-dendritic and axo-somatic GABAergic synapses on GABAA receptors containing the alphal subunit in Purkinje cells. J Neurosci 26:3245-3255.

Fukaya M, Watanabe M (2000) Improved immunohistochemical detection 
of postsynaptically located PSD-95/SAP90 protein family by protease section pretreatment: a study in the adult mouse brain. J Comp Neurol 426:572-586.

Furukawa T, Furshpan EJ (1963) Two inhibitory mechanisms in the Mauthner neurons of goldfish. J Neurophysiol 26:140-176.

Gabbott PL, Somogyi J, Stewart MG, Hamori J (1986) GABA-immunoreactive neurons in the rat cerebellum: a light and electron microscope study. J Comp Neurol 251:474-490.

Gianola S, Savio T, Schwab ME, Rossi F (2003) Cell-autonomous mechanisms and myelinassociated factors contribute to the development of Purkinje axon intracortical plexus in the rat cerebellum. J Neurosci 23:4613-4624.

Gobel S (1971) Axo-axonic septate junctions in the basket formations of the cat cerebellar cortex. J Cell Biol 51:328-333.

Howard A, Tamas G, Soltesz I (2005) Lighting the chandelier: new vistas for axo-axonic cells. Trends Neurosci 28:310-316.

Ichikawa R, Yamasaki M, Miyazaki T, Konno K, Hashimoto K, Tatsumi H, Inoue Y, Kano M, Watanabe M (2011) Developmental switching of perisomatic innervation from climbing fibers to basket cell fibers in cerebellar Purkinje cells. J Neurosci 31:16916-16927.

Itouji A, Sakai N, Tanaka C, Saito N (1996) Neuronal and glial localization of two GABA transporters (GAT1 and GAT3) in the rat cerebellum. Brain Res Mol Brain Res 37:309-316.

Jenkins SM, Bennett V (2001) Ankyrin-G coordinates assembly of the spectrin-based membrane skeleton, voltage-gated sodium channels, and L1 CAMs at Purkinje neuron initial segments. JCell Biol 155:739-746.

Jiao Y, Yan J, Zhao Y, Donahue LR, Beamer WG, Li X, Roe BA, Ledoux MS, Gu W (2005) Carbonic anhydrase-related protein VIII deficiency is associated with a distinctive lifelong gait disorder in waddles mice. Genetics 171:1239-1246.

Kasugai Y, Swinny JD, Roberts JD, Dalezios Y, Fukazawa $Y$, Sieghart W, Shigemoto R, Somogyi P (2010) Quantitative localisation of synaptic and extrasynaptic GABAA receptor subunits on hippocampal pyramidal cells by freeze-fracture replica immunolabelling. Eur J Neurosci 32:1868-1888.

Kaufman DL, McGinnis JF, Krieger NR, Tobin AJ (1986) Brain glutamate decarboxylase cloned in lambda gt-11: fusion protein produces gamma-aminobutyric acid. Science 232: $1138-1140$.

Kistner U, Wenzel BM, Veh RW, Cases-Langhoff C, Garner AM, Appeltauer U, Voss B, Gundelfinger ED, Garner CC (1993) SAP90, a rat presynaptic protein related to the product of the Drosophila tumor suppressor gene dlg-A. J Biol Chem 268:4580-4583.

KordeliE, Lambert S, BennettV (1995) AnkyrinG. A new ankyringene with neuralspecific isoforms localized at the axonal initial segment and node of Ranvier.J Biol Chem 270:2352-2359.

Korn H, Axelrad H (1980) Electrical inhibition of Purkinje cells in the cerebellum of the rat. Proc Natl Acad Sci U S A 77:6244-6247.

Kosaka T, Kosaka K, Nakayama T, Hunziker W, Heizmann CW (1993) Axons and axon terminals of cerebellar Purkinje cells and basket cells have higher levels of parvalbumin immunoreactivity than somata and dendrites: quantitative analysis by immunogold labeling. Exp Brain Res 93:483-491.

Kralic JE, Criswell HE, Osterman JL, O'Buckley TK, Wilkie ME, Matthews DB, Hamre K, Breese GR, Homanics GE, Morrow AL (2005) Genetic essential tremor in gamma-aminobutyric acidA receptor alphal subunit knockout mice. J Clin Invest 115:774-779.
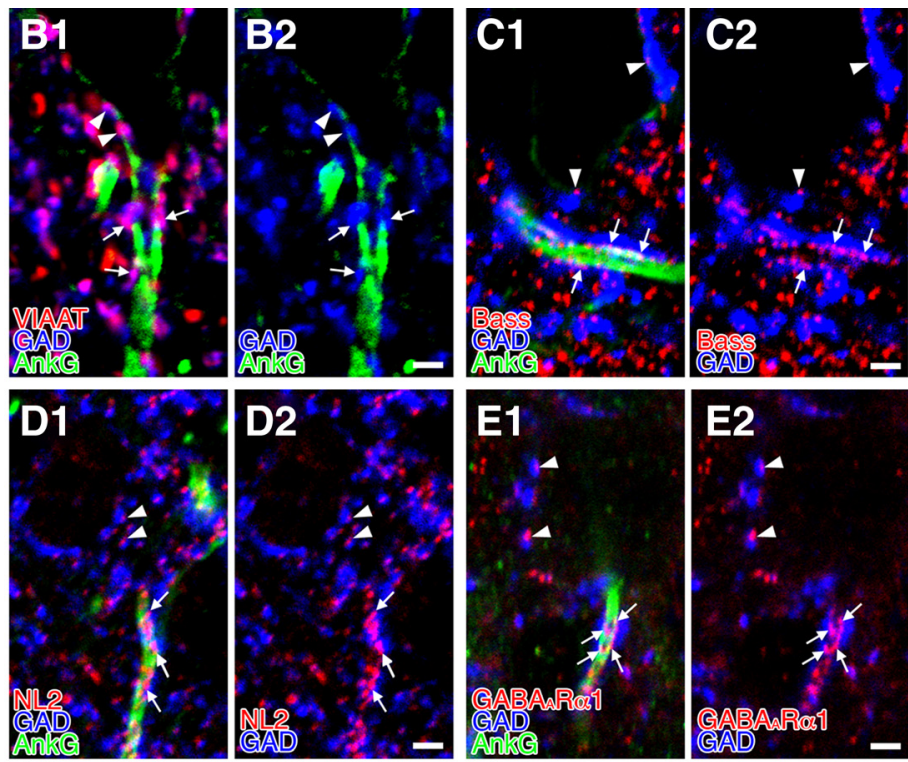

E2
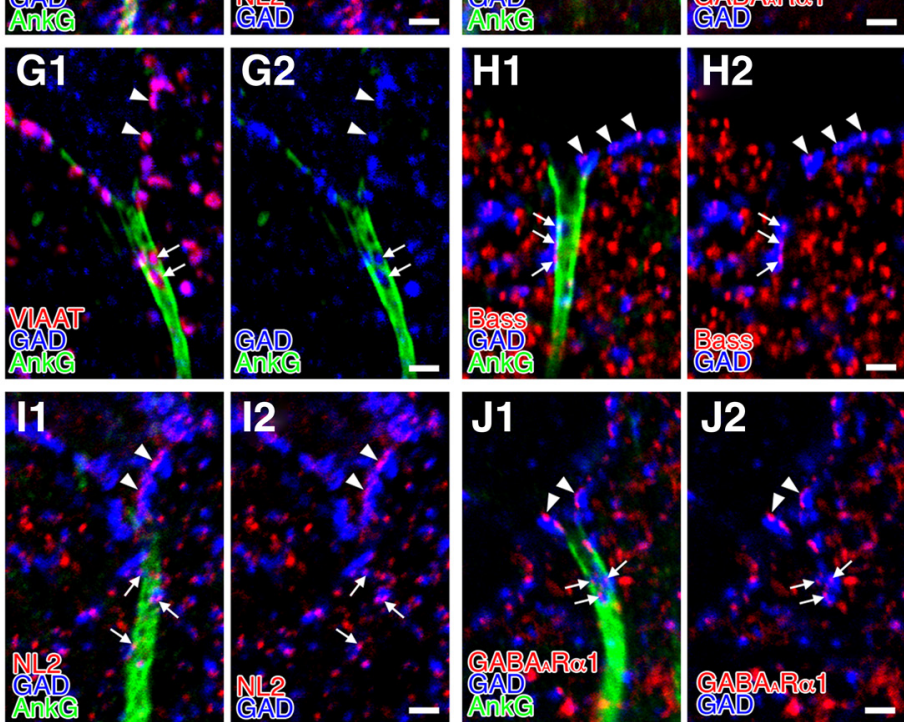

Figure 8. Functional molecular assembly for GABAergic synaptic transmission at axo-axonic contacts along the AIS of cortical ramidal cells. Triple immunofluorescence for AnkG (green; A, B1, B2, C1, D1, E1, F, G1, G2, H1, I1, J1), GAD (blue; all panels) in the AIS of pyramidal cells in the hippocampal CA3 $(\boldsymbol{A}-\boldsymbol{E})$ and somatosensory cortex $(\boldsymbol{F}-\boldsymbol{J})$. $\boldsymbol{B}$ and $\boldsymbol{G}$ are enlarged images from in $\boldsymbol{A}$ and $\boldsymbol{F}$. Signal clusters for VIAAT, Bass, NL2, and GABA ${ }_{A} R \alpha 1$ are aligned along AnkG-labeled AISs and apposed to $\mathrm{GAD}^{+}$terminal boutons (arrows), which is a similar distribution to those on pyramidal cell somata (arrowheads). Lu, Stratum lucidum; Or, stratum oriens; Py, pyramidal cell layer. Scale bars: $\boldsymbol{A}, \boldsymbol{F}, 10 \mu \mathrm{m} ; \boldsymbol{B}-\boldsymbol{E}, \boldsymbol{G}-\boldsymbol{J}, 2 \mu \mathrm{m}$.

Laube G, Röper J, Pitt JC, Sewing S, Kistner U, Garner CC, Pongs O, Veh RW (1996) Ultrastructural localization of Shaker-related potassium channel subunits and synapse-associated protein 90 to septate-like junctions in rat cerebellar Pinceaux. Brain Res Mol Brain Res 42:51-61.

Li XG, Somogyi P, Tepper JM, Buzsáki G (1992) Axonal and dendritic arborization of an intracellularly labeled chandelier cell in the CA1 region of rat hippocampus. Exp Brain Res 90:519-525.

Lowry OH, Rosebrough NJ, Farr AL, Randall RJ (1951) Protein measurement with the Folin phenol reagent. J Biol Chem 193:265-275.

McIntire SL, Reimer RJ, Schuske K, Edwards RH, Jorgensen EM (1997) Identification and characterization of the vesicular GABA transporter. Nature 389:870-876.

Miyazaki T, Fukaya M, Shimizu H, Watanabe M (2003) Subtype switching of vesicular glutamete transporters at parallel fibre-Purkinje cell synapses in developing mouse cerebellum. Eur J Neurosci 17:2563-2572.

Morara S, Brecha NC, Marcotti W, Provini L, Rosina A (1996) Neuronal and glial localization of the GABA transporter GAT-1 in the cerebellar cortex. Neuroreport 7:2993-2996.

Nakajima Y, Kohno K (1978) Fine structure of the Mauthner cell: synaptic 

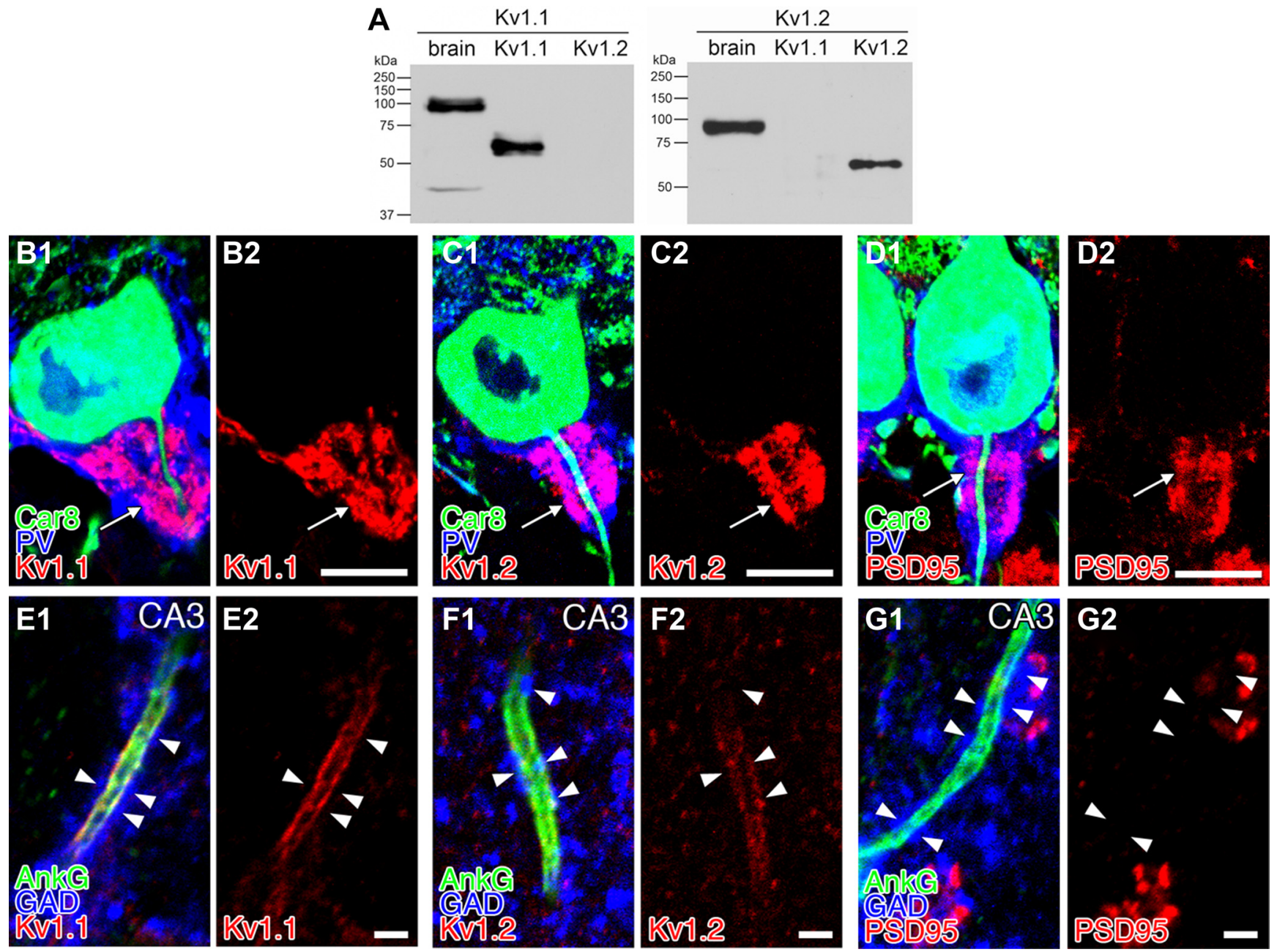

Figure 9. Distinct expression of Shaker-type potassium channels, $K_{y} 1.1$ and $K_{y} 1.2$, and their scaffold PSD-95 at axo-axonic contacts onto cerebellar PCs and hippocampal pyramidal cells. $A$, Immunoblot showing the specificity of rabbit $K_{v} 1.1$ and $K_{v} 1.2$ antibodies. In the left, rabbit $K_{v} 1.1$ antibody detects a $100 \mathrm{kDa}$ protein band in brain homogenates and a $60 \mathrm{kDa}$ band in $\mathrm{HEK}$ cell lysates transfected with mouse $K_{v} 1.1$ but not mouse $K_{v} 1.2 \mathrm{CDNA}$ (right). In the right, $\mathrm{K}_{\mathrm{v}} 1.2$ antibody detects a $90 \mathrm{kDa}$ protein band in brain homogenates (left lane) and a $60 \mathrm{kDa}$ band in HEK cell lysates transfected with mouse $K_{v} 1.2$ (right) but not mouse $K_{v} 1.1$ CDNA (middle). Different-sized bands seen in brain homogenates and HEK cell lysates may reflect different protein modifications. $\boldsymbol{B}-\boldsymbol{D}$, Triple immunofluorescence for Car8 (green; B1, C1, D1), PV (blue; B1, C1, D1), and one of Kv1.1 (red; B1, B2), Kv1.2 (red; C1, C2), and PSD-95 (red; D1, D2) in the pinceau formation (arrows). Note the enrichment of $\mathrm{K}_{\mathrm{v}} 1$ 1. $\mathrm{K}_{\mathrm{v}} 1.2$, and PSD-95 in the pinceau formation. E-G, Triple immunofluorescence for AnkG (green; E1, F1, G1), PV (blue; E1, F1, G1), and one of Kv1.1 (red; E1, E2), Kv1.2 (red; F1, F2), and PSD-95 (red; G1, G2) at axo-axonic contacts of hippocampal CA3 pyramidal cells. Note the lack of $K_{v} 1.1, K_{v} 1.2$, and PSD-95 in terminals of axo-axonic synapses in hippocampal CA3 pyramidal cells (arrowheads). $K_{v} 1.1$ and $K_{v} 1.2$ are instead detected on the AnkG ${ }^{+}$AIS. Scale bars, $10 \mu \mathrm{m}$.

topography and comparative study. In: Neurobiology of the Mauthner cell (Faber D, Korn H, eds). New York: Raven.

Nakamura M, Sato K, Fukaya M, Araishi K, Aiba A, Kano M, Watanabe M (2004) Signaling complex formation of phospholipase C $\beta 4$ with mGluR $1 \alpha$ and IP3R 1 at the perisynapse and endoplasmic reticulum in the mouse brain. Eur J Neurosci 20:2929-2944.

Nusser Z, Sieghart W, Benke D, Fritschy JM, Somogyi P (1996) Differential synaptic localization of two major gamma-aminobutyric acid type A receptor alpha subunits on hippocampal pyramidal cells. Proc Natl Acad Sci U S A 93:11939-11944.

Oertel WH, Schmechel DE, Mugnaini E, Tappaz ML, Kopin IJ (1981) Immunocytochemical localization of glutamate decarboxylase in rat cerebellum with a new antiserum. Neuroscience 6:2715-2735.

Ogawa Y, Rasband MN (2008) The functional organization and assembly of the axon initial segment. Curr Opin Neurobiol 18:307-313.

Palay S, Chan-Palay V (1974) Cerebellar cortex cytology and organization. Berlin: Springer.

Palay SL, Sotelo C, Peters A, Orkand PM (1968) The axon hillock and the initial segment. J Cell Biol 38:193-201.

Patrizi A, Scelfo B, Viltono L, Briatore F, Fukaya M, Watanabe M, Strata P, Varoqueaux F, Brose N, Fritschy JM, Sassoè-Pognetto M (2008) Synapse formation and clustering of neuroligin-2 in the absence of GABAA receptors. Proc Natl Acad Sci U S A 105:13151-13156.
Peters A, Feldman M, Saldanha J (1976) The projection of the lateral geniculate nucleus to area 17 of the rat cerebral cortex. II. Terminations upon neuronal perikarya and dendritic shafts. J Neurocytol 5:85-107.

Peters A, Proskauer CC, Ribak CE (1982) Chandelier cells in rat visual cortex. J Comp Neurol 206:397-416.

Richter K, Langnaese K, Kreutz MR, Olias G, Zhai R, Scheich H, Garner CC, Gundelfinger ED (1999) Presynaptic cytomatrix protein bassoon is localized at both excitatory and inhibitory synapses of rat brain. J Comp Neurol 408:437-448.

Roman y Cajal S (1911) Histolory of the nervous system of man and vertebrates. Oxford: Oxford UP.

Rosina A, Morara S, Provini L (1999) GAT-1 developmental expression in the rat cerebellar cortex: basket and pinceau formation. Neuroreport 10:1613-1618.

Shibata T, Yamada K, Watanabe M, Ikenaka K, Wada K, Tanaka K, Inoue Y (1997) Glutamate transporter GLAST is expressed in the radial gliaastrocyte lineage of developing mouse spinal cord. J Neurosci 17:9212-9219.

Somogyi P (1977) A specific "axo-axonal" interneuron in the visual cortex of the rat. Brain Res 136:345-350.

Somogyi P, Hamori J (1976) A quantitative electron microscopic study of the Purkinje cell axon initial segment. Neuroscience 1:361-365. 
Somogyi P, Freund TF, Cowey A (1982) The axo-axonic interneuron in the cerebral cortex of the rat, cat and monkey. Neuroscience 7:2577-2607.

Somogyi P, Freund TF, Hodgson AJ, Somogyi J, Beroukas D, Chubb IW (1985) Identified axo-axonic cells are immunoreactive for GABA in the hippocampus and visual cortex of the cat. Brain Res 332:143-149.

Sotelo C (2008) Development of "Pinceaux" formations and dendritic translocation of climbing fibers during the acquisition of the balance between glutamatergic and gamma-aminobutyric acidergic inputs in developing Purkinje cells. J Comp Neurol 506:240-262.

Sotelo C, Llinás R (1972) Specialized membrane junctions between neurons in the vertebrate cerebellar cortex. J Cell Biol 53:271-289.

tom Dieck S, Sanmartí-Vila L, Langnaese K, Richter K, Kindler S, Soyke A, Wex H, Smalla KH, Kämpf U, Fränzer JT, Stumm M, Garner CC, Gundelfinger ED (1998) Bassoon, a novel zinc-finger CAG/glutaminerepeat protein selectively localized at the active zone of presynaptic nerve terminals. J Cell Biol 142:499-509.

Triller A, Korn H (1980) Glio-axonic junctional like complexes at the Mauthner cell's axon cap of teleosts: a possible morphological basis for field effect inhibitions. Neurosci Lett 18:275-281.

Varoqueaux F, Jamain S, Brose N (2004) Neuroligin 2 is exclusively localized to inhibitory synapses. Eur J Cell Biol 83:449-456.
Wang H, Kunkel DD, Schwartzkroin PA, Tempel BL (1994) Localization of Kv1.1 and Kv1.2, two K channel proteins, to synaptic terminals, somata, and dendrites in the mouse brain. J Neurosci 14:4588-4599.

Watanabe M, Fukaya M, Sakimura K, Manabe T, Mishina M, Inoue Y (1998) Selective scarcity of NMDA receptor channel subunits in the stratum lucidum (mossy fibre-recipient layer) of the mouse hippocampal CA3 subfield. Eur J Neurosci 10:478-487.

Weiss SA, Faber DS (2010) Field effects in the CNS play functional roles. Front Neural Circuits 4:15.

Yamada K, Watanabe M, Shibata T, Nagashima M, Tanaka K, Inoue Y (1998) Glutamate transporter GLT-1 is transiently localized on growing axons of the mouse spinal cord before establishing astrocytic expression. J Neurosci 18:5706-5713.

Yamada K, Fukaya M, Shimizu H, Sakimura K, Watanabe M (2001) NMDA receptor subunits GluRe1, GluRe3, and GluR $\zeta 1$ are enriched at the mossy fiber-granule cell synapse in the adult mouse cerebellum. Eur J Neurosci 13:2025-2036.

Zhou D, Lambert S, Malen PL, Carpenter S, Boland LM, Bennett V (1998) AnkyrinG is required for clustering of voltage-gated $\mathrm{Na}$ channels at axon initial segments and for normal action potential firing. J Cell Biol 143:1295-1304. 